\title{
AINDA A PROPÓSITO DA RECEPÇÃO (OU PERCEPÇÃO) DO CINISMO ANTIGO \\ nota sobre um outro caso*
}

\author{
Olimar Flores-Júnior** \\ Universidade Federal de Minas Gerais
}

And is it not, among our communists of today, the same Cynic poison that continues its corrosive operation?

W. Amelung

\begin{abstract}
RES U M O
Este artigo comenta a referência ao cinismo antigo em matéria publicada em uma revista brasileira de grande circulação, criticando o vínculo que nela é estabelecido entre a criminalidade contemporânea e o pensamento de Diógenes de Sínope.
\end{abstract}

PALAVRAS - CHAVE

Cinismo, crime, liberdade

Depois de ter comentado num outro artigo, publicado nesta mesma revista, dois casos de apropriação do cinismo antigo, um pela psiquiatria e outro pela psicanálise, ${ }^{1}$ volto, neste brevíssimo texto, a mais uma incursão do mundo contemporâneo pela filosofia de Diógenes. O caso desta vez, que mal pode ser comparado aos outros dois que me ocuparam anteriormente, não mereceria qualquer esforço de análise, dada a superficialidade quase caricata da referência ao pensamento cínico e o que dele se pôde inferir, numa combinação rara de ousadia e ignorância. Todavia, dois aspectos parecem justificar a pena: em primeiro lugar, o fato de que tal apropriação, nos moldes em que foi feita, constitua o sintoma de uma recepção que tem suas raízes no mundo antigo, embora a continuidade que se identifica aí apareça substituída por uma confusão estapafúrdia entre cinismo antigo (filosófico) e cinismo moderno (ligado ao uso corrente do adjetivo cínico), esse último tratado também de forma abusiva $;^{2}$ em segundo lugar

\footnotetext{
* Uma versão preliminar deste artigo foi apresentada oralmente na mesa-redonta "A recepção dos clássicos", por ocasião da VII Semana de Eventos da Faculdade de Letras da UFMG (SEVFALE), nos dias 1 a 5 de outubro de 2007.

**ofloresj@yahoo.com.br

${ }^{1}$ Cf. FLORES-JÚNIOR. Usos e abusos da Antigüidade Clássica: sobre as apropriações do cinismo grego.

${ }^{2}$ Assunto complexo que, sobretudo depois da publicação, em 1983, do polêmico Crítica da razão cínica de Peter Sloterdijk (SLOTERDIJK. Kritik der zynischen Vernunft), tem feito correr muita tinta.
} 
(sem que se queira aqui investir um discurso corretivo ou vigilante das práticas da comunicação social), o fato de que o que pretendo expor revela o modo leviano - a serviço, deve-se dizer, das boas intenções e de um civismo louvável sob muitos aspectos - com que a imprensa de massa aborda, em nome de uma suposta acessibilidade e de uma maior eficácia comunicativa, não só a história (no caso a da filosofia), mas também outros temas graves, de que dependem mesmo a saúde da sociedade.

Trata-se de uma matéria publicada no número de agosto de 2007 pela revista Cláudia. ${ }^{3}$ Entre os títulos de capa, que anunciam os principais temas que compõem o número, como, por exemplo, "feliz cabelo novo: leitoras testam as escovas progressivas liberadas pela Anvisa", "204 idéias de moda", "3 testes de sexo: avalie o seu talento erótico", "por que tantas mulheres incríveis namoram, namoram e continuam sozinhas" e, como que para prestar um serviço mais sério, "as novas armadilhas das entrevistas de emprego: como ser a escolhida", podemos ler, sem grande destaque, a seguinte chamada: “jovens de classe média, perversos e sem limites: onde suas famílias perderam a mão?".

A matéria correspondente - na verdade um "artigo exclusivo", assinado pela psicoterapeuta Lídia Aratangy - ocupa as páginas 134 a 138, encaixada entre um anúncio de página inteira de um regulador intestinal fitoterápico e um outro sobre a campanha do autoexame no combate ao câncer de mama, se interroga, a partir de fatos mais ou menos recentes da crônica policial, sobre as razões da violência e da brutalidade crescente nas grandes cidades. A matéria parece externar o incômodo diante do fato de que uma perversidade aparentemente gratuita tenha saído dos guetos para alcançar a classe média, que nela se reconhece não mais apenas como vítima, mas como sujeito. Eis o histórico dos fatos: "Abril de 1997: em Brasília, três adolescentes jogam álcool e ateiam fogo num homem adormecido perto de um ponto de ônibus. O homem, Galdino, um índio pataxó que participava de um encontro indígena, não resistiu às queimaduras e morreu dias depois. Os jovens alegaram que era apenas uma brincadeira e que confundiram o índio com um mendigo"; "Fevereiro de 1999: após uma festa de confraternização de calouros e veteranos da Faculdade de Medicina da USP, o calouro Edison Hsueh é encontrado morto dentro da piscina do centro acadêmico. Segundo o delegado que atendeu o caso, o mais provável é que ninguém tenha se disposto a ajudar o colega, que não sabia nadar e se afogou. Um faxineiro encontrou o corpo cerca de nove horas depois, na piscina escurecida pelo excesso de sujeira e cloro"; Dezembro de 2005: três universitários da PUC de Campinas são presos sob a acusação de dopar e estuprar uma colega"; Junho de 2007: a empregada doméstica Sirlei Dias é roubada e espancada por cinco jovens de classe média do Rio de Janeiro. Os agressores alegaram ter confundido a vítima com uma prostituta”.

Em meio aos argumentos evocados para compreender e, por consequência, ajudar a evitar esses tipos de atrocidade, a psicoterapeuta escreve, num parágrafo marcado com o subtítulo "o grande risco": "o maior perigo que ameaça nossos adolescentes não é a Aids, o abuso de drogas nem a gravidez indesejada: é o cinismo”. A afirmação, isolada

\footnotetext{
${ }^{3}$ Agradeço o conhecimento dessa matéria à minha colega Laura Guimarães, profa. do Departamento de Comunicação da FAFICH/UFMG, cuja pesquisa sobre publicidade obriga à coleta e ao exame sistemático desse tipo de publicação.
} 
de seu contexto, passaria provavelmente despercebida e cairia no senso comum do uso corrente e quase inócuo da ideia contemporânea de cinismo: a grande ameaça do mundo moderno, sobretudo nos grandes centros urbanos, seria então a desfaçatez, a impudência e o descaramento que nascem da crise dos valores morais. Mas no conjunto da matéria, o cínico, um patife até certo ponto inofensivo, aparece com as roupas do facínora. Mas o problema não termina aí. Desejando talvez fundamentar a sua análise com a autoridade da história antiga - e acrescentando assim uma nota de erudição ao seu texto -, a autora insere num box a informação que ela julga necessária para o entendimento de seu ponto de vista: "O cinismo. A filosofia cínica surgiu em Atenas por volta de 400 a. C. O nome tem origem na palavra grega kinikós (referente a cães), pelas ideias radicais de liberdade, que levaram a um modo de vida despudorado, com ataques às tradições e aos valores sociais. Sua forma mais radical defendia a resposta individual diante de uma sociedade alienante e opressora e pregava a transgressão contínua dos valores tradicionais e das normas sociais. Os cínicos consideravam-se cidadãos do mundo e, portanto, liberados da obediência a convenções e leis, já que estas estão ligadas a condições geográficas e temporais".

Não cabe aqui comentar, ponto por ponto, essa descrição sumária e simplificadora da filosofia cínica, que a rigor, como acontece frequentemente nesses casos, não está incorreta. Mas convém notar, que à força de resumir e generalizar, ela acumula truísmos que, podendo valer para outras tantas doutrinas ou correntes de pensamento, pouco servem para diferenciar o cinismo. Poderia, por exemplo, mostrar que o cinismo foi sim um movimento que transgrediu sistematicamenste os valores tradicionais e as nomas sociais, e que nesse sentido ele se aproximava bastante do cristianismo das origens, que também se opunha à ordem do poder instituído. Poderia igualmente mostrar que o individualismo cínico reveste na verdade uma filantropia universal que está na base de seu cosmopolitismo - também sobre esse ponto não seria de todo improcedente uma comparação com a doutrina cristã que, embora sobre outras bases, prega a fraternidade entre todos os homens. Nesse sentido, não falta mesmo quem, ainda que com argumentos nem sempre convincentes, se arrisque a compor a imagem de um Jesus cínico. ${ }^{4}$

Seria interessante mostrar também que o cosmopolitismo cínico visa à supressão não apenas das grandes demarcações políticas, "ligadas a condições geográficas e temporais" - cidades e estados nacionais, por exemplo -, como também da célula matricial da sociedade, a família, pregando a comunhão de mulheres e crianças, e afirmando que não há razão alguma para ter gratidão por nossos pais pelo simples fato de que eles nos geraram, já que é a natureza que determina toda geração. ${ }^{5}$ A partir daí, seria necessário explicar que a ordem política proposta pelos cínicos não pode ser reduzida a uma mera corrupção das relações familiares: os cínicos, na verdade, colocaram a virtude à frente dos laços de parentesco e das coerções convencionais da sociedade.

\footnotetext{
${ }^{4}$ Vejam-se os trabalhos de F. Gerald Downing, dentre os quais destacaria DOWNING. Jesus and the Threat of Freedom (em especial o capítulo "Jesus as Cynic", p. 126-160); DOWNING. Christ and the cynics: Jesus and Other Radicals Preachers in the First Century Tradition; DOWNING. Cynics and Christian Origins. Para uma crítica da hipótese de um Jesus cínico, veja-se o artigo de BETZ. Jesus and the Cynics: survey and analysis of a hypothesis.
}

${ }^{5}$ Cf. Pseudo-Diógenes, Carta XXI, a Aminandro (SSR V B 551). 
Poderia, por outro lado, explorar a já referida passagem do sentido filosófico que o cinismo teve na Antiguidade para o sentido moderno e vulgar do termo "cínico". Tal percurso, longo e acidentado, nos obrigaria a duas paradas obrigatórias: a primeira, na relação conturbada entre cinismo e estoicismo - em que também filósofos da escola de Epicuro desempenharam um papel importante -, a partir da qual se inicia a deturpação progressiva - muitas vezes voluntária e programática, como no caso do epicurista Filodemo de Gadara - da doutrina cínica; ${ }^{6}$ e a segunda, no Século das Luzes, em que se reconheceu na figura de Diógenes não apenas o triunfo da razão absoluta como também o seu reverso perfeito. ${ }^{7}$ Assim, em $O$ sobrinho de Rameau, de Diderot, exemplo máximo do cinismo iluminista, o personagem identificado genérica e provocativamente apenas como o "filósofo", e que reveste a primeira pessoa do discurso, trava uma conversação com a outra personagem, o "sobrinho", algo como um Diógenes enlouquecido, ${ }^{8}$ recriado com o ar daqueles tempos, um "misto de altivez e de baixeza, de bom senso e desatino". ${ }^{9}$ Tudo isso seria muito longo. Contentemo-nos com essas breves - e algo enigmáticas - indicações pouco desenvolvidas.

Para voltar à matéria da revista, o que de fato gostaria de comentar é a afirmação, feita sem mais, segundo a qual o cinismo defendia "ideias radicais de liberdade" e que essas ideias "levavam seus seguidores a um modo de vida despudorado, com ataques às tradições e aos valores sociais". Dizer que o cinismo se caracteriza por "ideias de liberdade" está correto, mas o mesmo traço pode ser identificado em todas as grandes escolas filosóficas do período helenístico, e, de modo geral, toda a filosofia grega está marcada pela busca de princípios que possam garantir ao homem a liberdade tanto frente aos medos que lhe são inerentes, quanto frente às ameaças objetivas do mundo exterior.

Assim, dizer que os cínicos sustentavam "ideias radicais de liberdade" diz finalmente muito pouco sobre o cinismo. Mas o que a explicação sobre o cinismo dada no pequeno box silencia pode ser depreendido do conjunto da matéria. Tratando da importância da educação - formal, escolar ou familiar - dos jovens, a psicoterapeuta identifica no excesso de liberdade um dos responsáveis por futuros desvios de comportamento ou moralidade: "Alguns pais, por não tolerar a frustração dos filhos, não colocam limites claros e coerentes. Esquecem que a frustração é parte da vida, e não uma falha no processo de desenvolvimento. Crianças que não aprendem a lidar com a frustração tornam-se impacientes e birrentas e tendem a transforma-se em adolescentes insatisfeitos, que não suportam o adiamento das satisfações." Tudo muito bem, de um

\footnotetext{
${ }^{6}$ Consulte-se a propósito o excelente estudo de GOULET-CAZÉ. Les kynika du stoïcisme.

${ }^{7}$ Tome-se como exemplo O Sobrinho de Rameau de Diderot.Veja-se sobre o assunto o artigo de NIEHUESPRÖBSTING. Der Kynismus-Rezeption der Moderne: Diogenes in der Aufklärung.

${ }^{8}$ Essa comparação não faz mais que recuperar uma outra, que a Antiguidade nos comunicou: "Interrogado por alguém: 'Para você, que tipo de homem Diógenes parece ser?', ele [Platão] falou: 'Um Sócrates enlouquecido (mainómenos)." (D.L. VI 54). Salvo indicação contrária, todas as traduções são de minha responsabilidade.

${ }^{9}$ Tradução de Marilena Chauí, em DIDEROT. O sobrinho de Rameau. Cf. sobre o assunto o artigo de NIEHUES-PRÖBSTING. Der Kynismus-Rezeption der Moderne: Diogenes in der Aufklärung e, especificamente sobre o Sobrinho de Rameau, o ensaio de TORRES FILHO. Cinismo ilustrado.
} 
ponto de vista pedagógico, mas a autora, involuntariamente talvez, cola ao cinismo um ideal de liberdade que lhe é completamente estranho. Os cínicos pregam não uma liberdade para, que se depreende do comportamento excessivo de jovens mal educados, mas uma liberdade de, mais no sentido de uma liberação: ${ }^{10}$ liberação das paixões e dos medos, por exemplo. Nesse aspecto, como disse, os cínicos não se diferenciam do conjunto da filosofia grega. A diferença consiste justamente no radicalismo com que tal liberdade era praticada, mas para entender esse radicalismo seria necessário perceber o fundo do qual ele se destaca.

O tema da liberdade na filosofia grega é obviamente vasto demais para ser tratado aqui. Gostaria apenas de retomar uma imagem bastante conhecida - e a interpretação luminosa que lhe dá Pierre Hadot, em seu Exercícios espirituais e filosofia antiga, publicado pela primeira vez em $1993^{11}$ - no intuito de ilustrar a concepção de liberdade que pode ser depreendida da filosofia do período helenístico. Trata-se da metáfora da "escultura de si", tal como a formulou Plotino: ${ }^{12}$

Se tu não vês ainda tua própria beleza, faz como o escultor de uma estátua que tem que ser bela: ele tira aqui, ele raspa ali, ele alisa tal parte, limpa outra, até que apareça um belo rosto. Da mesma maneira, tu também, tira tudo o que é supérfluo, endireita o que é oblíquo, purificando o que é nebuloso para torná-lo brilhante. E não cesses de esculpir tua própria estátua até que brilhe em ti a clareza divina da virtude. ${ }^{13}$

Mais importante aqui é o alcance ético da metáfora que Plotino coloca a serviço de seu misticismo. A escultura é uma arte da eliminação, da redução - poderíamos dizer: da liberação -, ao contrário da pintura, que seria uma arte do acréscimo: acrescentam-se traços e cores que compõem ao fim a figura desejada. A escultura clássica parte de um bloco maciço de pedra ou madeira e, num processo que consiste em retirar e subtrair os excessos, atinge-se a imagem buscada. Da mesma forma se dá a construção moral do homem: só aquele que se libera das paixões e dos medos pode pretender à virtude e à felicidade.

Mas se em Plotino, essa forma de liberdade se expressa em termos abstratos, ela ganha contornos mais nítidos com outras escolas. Epicuro, por exemplo, afirmava que só não teme os riscos da vida quem aprendeu a se libertar do medo de morrer e, para justificar, ajuntava o seguinte raciocínio: “o mais terrível dos males, a morte, não é nada para nós, pois, justamente, quando nós somos, a morte não está, e se ela está,

\footnotetext{
${ }^{10} \mathrm{Cf}$. a introdução da coletânea de estudos sobre o cinismo de GOULET-CAZÉ ; BRACHT BRANHAM. The Cynics. The Cynic Movement in Antiquity and its legacy, p. 9, que remete para BERLIN. Two concepts of liberty.

${ }^{11}$ HADOT. Exercises spirituels et philosophie antique.

${ }^{12}$ A expressão "escultura de si" dá título a um ensaio de Michel Onfray (ONFRAY. La sculpture de soi: la morale esthétique), publicado no mesmo ano em que o livro de Pierre Hadot. Mas a interpretação, de fatura nietzschiana, que Onfray dá àquela expressão, diverge profundamente da de Hadot, que recusa por sua parte a dimensão de um "estetismo moral".

${ }^{13}$ Plotino, Ennéades IV 7, 10, 27 e ss. (tradução de Bréhier, ligeiramente modificada), apud HADOT. Exercises spirituels et philosophie antique, p. 58-59.
} 
somos nós que já não estamos". ${ }^{14}$ Conta-se de Diógenes uma anedota que exprime exatamente a mesma "ideia de liberdade" e que revela o mesmo materialismo sem arestas: perguntado se a morte, isto é, a própria morte, era um mal, o Cínico afirmou: "como poderia ser um mal, ela que nós não sentimos quando ela está junto de nós?"15

Quanto às ameaças objetivas do mundo exterior, basta que se pense que na época tornar-se escravo era um perigo bem real: uma simples viagem de barco podia ser interrompida pelo ataque de piratas e qualquer um a bordo podia ser capturado e vendido em alguma terra distante. Com esse fundo temático, toda uma tradição literária conta que o próprio Diógenes foi, certa vez, capturado e vendido como escravo, mas que mesmo nessa situação soube conservar a liberdade de seu espírito, construída precisamente sobre um ideal de ataraxia e de independência com relação ao que é externo ao próprio sujeito. Se estamos diante de um fato histórico ou de mais uma das muitas fabulações em torno da biografia de Diógenes, é um problema secundário. Interessa, ao contrário, reconhecer que a Antiguidade fixou a imagem do cínico como alguém que sabia conservar sua liberdade independentemente das circunstâncias.

Mas a questão pode retornar: o que de fato diferencia a liberdade cínica da liberdade propugnada por outras filosofias? O que empresta às ideias de liberdade de Diógenes o radicalismo de que se fala? Como outros filósofos, os cínicos buscavam uma forma de ataraxia que significava precisamente a liberdade das paixões que normalmente vitimam o homem. Mas eles foram mais longe, ao estender - ou melhor reduzir - os limites da liberdade segundo as prescrições da natureza. Se o filósofo cínico, enquanto homem, se sujeitar ao que lhe impõe as necessidades naturais - ele deve, por exemplo, se alimentar -, isso não o impede de sonhar com a liberdade e a independência de um homem mais forte que a própria natureza. Cabe aqui relembrar a já gasta - mas sempre eficaz - anedota sobre a kheirourgía de Diógenes: conta-se que ele tinha o hábito de se masturbar em praça pública, à vista de todos, acompanhando a façanha da seguinte reflexão: "que bom seria, se esfregando também a barriga a fome passasse". ${ }^{16}$ Aos olhos dos "valores tradicionais" e das "normas sociais", o gesto de Diógenes é sem dúvida despudorado, mas por isso mesmo tem valor pedagógico. E, seguindo a lógica de uma razão absoluta, pode ainda justificar a moralidade de tudo que é natural, como as uniões de Crates e Hipárquia: o que não é errado fazer, não é errado fazer em público. ${ }^{17}$

Que o cinismo represente uma moral subversiva parece-me claro, mas não acredito que possa ser considerado como a inspiração longínqua de qualquer crime. Lemos ao fim da matéria que comentei o parágrafo melancólico: "Houve um tempo em que nos perguntamos que mundo deixaríamos para nossos filhos. Agora que aprendemos a cuidar melhor do planeta, o desafio está em preparar bem as mãos que herdarão a Terra. A complacência, a preguiça e a covardia não são bons parceiros nessa tarefa.” Desses vícios, o cinismo nunca foi a causa, mas bem pode ser a cura: já na Antiguidade,

\footnotetext{
${ }^{14}$ Cf. D.L. X 124-125.

${ }^{15}$ Cf. D.L. VI 68 e Cícero, Tusculanas I 43, 104 (SSR V B 105).

${ }^{16}$ Cf. D.L. VI 46; VI 69.

${ }^{17}$ Cf. D.L. VI 97.
} 
Antístenes era acusado de frequentar homens vis, ao que ele com firmeza respondia: "os médicos também freqüentam os doentes, mas nem por isso contraem a febre"; ${ }^{18}$ ou numa versão diferente, atribuída desta vez a Diógenes: "o sol também penetra nas latrinas, mas não se deixa sujar". ${ }^{19}$

-

\section{RÉ S U MÉ}

Cet article commente la référence au cynisme ancien dans un texte publié par une revue brésilienne de grande circulation, en critiquant le lien que l'on y a pu établir entre la criminalité contemporaine et la pensée de Diogène de Sinope.

\section{MOTS - CLÉS}

Cynisme, crime, liberté

\section{REFERÊNCIAS}

\section{FONTES PRIMÁRIAS}

DIDEROT, D. O sobrinho de Rameau. Trad. Marilena Chauí. São Paulo: Abril Cultural, 1973. p. 337-380. (Coleção Os pensadores).

DIOGENES LAERTIUS. Lives of eminent philosophers. With an English translation by R. D. Hicks. $2^{\text {nd }}$. Cambridge, Mass./London: Harvard University Press, 1991. 2 v. 549 p., 704 p. [D.L.] (col. "The Loeb Classical Library").

DIOGÈNE LAËRCE. Vies et doctrines des philosophes illustres. Traduction française sous la direction de M.-O. Goulet-Cazé. Paris: Le Livre de Poche, 1999. 1398 p. [D.L.]

GIANNANTONI, G. Socratis et socraticorum reliquiae. Collegit, disposuit, apparatibus notisque instruxit G. Giannantoni. 2 ed. Napoli: Bibliopolis, 1990. 4 v. 521 p., 652 p., 301 p., 609 p. [SSR]

\section{FONTES SECUNDÁRIAS}

BERLIN, I. Two Concepts of Liberty. In: . Four Essays on Liberty. Oxford, 1979.

BETZ, H. D. Jesus and the Cynics: Survey and Analysis of a Hypothesis. The Journal of Religion, v. 74, n. 4, p. 453-475, 1994.

BRACHT BRANHAM, R.; GOUlET-CAZÉ, M.-O. (Ed.). The Cynics. The Cynic Movement in Antiquity and Its Legacy. Berkeley: University of California Press, 1996. 456 p.

DOWNING, F. G. Jesus and the Threat of Freedom. London: SMC, 1987.

\footnotetext{
${ }^{18}$ Cf. D.L. VI 6.

${ }^{19}$ Cf. D.L. VI 63.
} 
DOWNING, F. G. Christ and the Cynics: Jesus and Other Radicals Preachers in the First Century Tradition. Sheffield, Enganld: JSOT Press, 1988. 232 p.

DOWNING, F. G. Cynics and Christian Origins. Edinburgh: T. \& T. Clark, 1992. 377 p. FLORES-JÚNIOR, O. Usos e abusos da Antigüidade clássica: sobre as apropriações do cinismo grego. Aletria, Belo Horizonte, v. 13, p. 175-191, 2006.

GOULET-CAZÉ, M.-O. Les kynika du stoïcisme, Band 89, Stuttgart: Franz Steiner Verlag, 2003. 198 p. (col. "Hermes Einzelschriften").

HADOT, P. Exercises spirituels et philosophie antique. 2. ed. Paris: Albin Michel, 2002. $407 \mathrm{p}$.

NIEHUES-PRÖBSTING, H. Der Kynismus-Rezeption der Moderne: Diogenes in der Aufklärung. In: GOUlET-CAZÉ, M.-O.; GOUlET, R. (Ed.). Le Cynisme ancien et ses prolongements. Paris: P. U. F., 1993. p. 519-555 (versão inglesa do autor: The modern reception of Cynicism: Diogenes in the Enlightenment. In: BRANHAM, R. Bracht; GOUlET-CAZÉ, M.-O. (Ed.). The Cynics. The Cynic movement in Antiquity and its legacy. Berkeley: University of California Press, 1996. p. 329-365).

ONFRAY, M. La sculpture de soi: la morale esthétique. Paris: Grasset, 1993. 286 p. (trad. brasileira: A escultura de si. Trad. Mauro Pinheiro. Rio de Janeiro: Rocco, 1995. 210 p.). TORRES FILHO, R. R. Cinismo ilustrado. In: . Ensaios de filosofia ilustrada. São Paulo: Brasiliense, 1987. p. 53-69.

SLOTERDIJK, P. Kritik der zynischen Vernunft. Frankfurt am Main: Suhrkamp, 1983. 2 v. 960 p. 